\title{
Clinical Events Reported Term
}

National Cancer Institute

\section{Source}

National Cancer Institute. Clinical Events Reported Term. NCI Thesaurus. Code C88021.

An account or report of a clinical event. 